\title{
PENGARUH TEAMWORK DAN PENGHARGAAN PADA KINERJA KARYAWAN HOTEL BINTANG TIGA DI SURABAYA
}

\author{
Nur Aini $1^{*}$ \\ ${ }^{1}$ STIA Bayuangga Probolinggo \\ *Penulis Korespondensi; Email: na347724@gmail.com
}

\begin{abstract}
Abstrak
Tujuan dari penelitian ini adalah untuk mengetahui dan menganilisis pengaruh teamwork dan penghargaan pada kinerja karyawan. Sampel penelitian adalah 100 responden dari populasi sebanyak 134 karyawan hotel bintang tiga di Surabaya. Hasil penelitian ini ialah teamwork dan penghargaan berpengaruh positif dan signifikan pada kinerja karyawan dan variabel penghargaan memiliki pengaruh dominan pada kinerja karyawan hotel bintang tiga di Surabaya.
\end{abstract}

Kata Kunci: Teamwork, penghargaan, kinerja.

\begin{abstract}
The objective of this study was to identify and analyze the influence of teamwork and rewards on employee performance. The research sample were 100 respondents from a population of 134 employees of three stars hotel in Surabaya. The results were teamwork and rewards affected employee performance positively and significant and rewards had a dominant influence to performance of the three stars hotel in Surabaya employees.
\end{abstract}

Keywords: Teamwork, rewards, performance.

\section{Pendahuluan}

Sumberdaya manusia yang ada dalam suatu organisasi memiliki keanekaragaman yang cukup tinggi. Dengan diversity yang cukup tinggi tersebut berarti kemampuan sebagai agent of change juga akan berbedabeda. Usaha perubahan organisasional yang membutuhkan partisipasi dari semua karyawan akan tercapai apabila ada kemauan dari masing-masing karyawan untuk bisa berperan sebagai agen perubahan. Ketika organisasiorganisasi berusaha mengadaptasi perubahan lingkungan yang meningkat serta intensitas persaingan yang cepat, efektivitas organisasi atau bahkan kelangsungan hidupnya akan bergantung pada kemampuan manajemen dalam memberdayagunakan dan memimpin pekerja-pekerja organisasi untuk menerapkan strategi usaha yang kuat dan berkelanjutan untuk mencapai tujuan organisasi. Unsur manusia merupakan modal yang sangat penting, maka perlu untuk dijaga dan dipelihara kinerjanya agar tetap baik. Goleman (dalam Mangkunegara, 2005b) mengatakan bahwa "pencapaian kinerja ditentukan hanya 20 persen dari IQ, sedangkan 80 persen lagi ditentukan oleh kecerdasan emosi (EQ/Emotional Quotion)." Selanjutnya, Beck (2000) mengatakan bahwa IQ dapat berkembang menjadi 50 persen sebelum usia lima tahun. Sebelum delapan tahun IQ berkembang menjadi 80 persen, dan 20 persen sisanya berkembang pada saat usia remaja. Kecerdasan emosi (EQ) dapat dikembangkan terus-menerus tanpa adanya batas waktu. Oleh karena itu, sebagai pimpinan organisasi jika mengharapkan pencapaian kinerja maksimal di organisasinya, upaya paling tepat adalah bagaimana membina diri dan membina SDM bawahan untuk memiliki kecerdasan emosi yang baik. Indah, Rahmawati, dan Andiani (2019) menyimpulkan bahwa pemberian penghargaan (rewards) memiliki efek yang sangat positif pada kinerja karyawan. Oleh karena itu, pimpinan organisasi harus berusaha keras memengaruhi seluruh individu organisasi agar memiliki motivasi untuk berkinerja yang baik.

Menurut Moekijat (2002) pengertian kinerja yang berkaitan dengan kemampuan kelompok adalah kemampuan sekelompok orang-orang untuk bekerja dengan giat dan konsekuen menunjukkan caranya untuk sampai pada tujuan melalui disiplin bersama. Unsur penting dari kinerja adalah adanya keinginan untuk mencapai tujuan dari sekelompok atau merujuk kepada adanya kebersamaan.

Untuk bisa tetap menjaga kinerja karyawan, perusahaan perlu membentuk teamwork (kerjasama antar karyawan) yang merupakan sekelompok orang yang memiliki tujuan bersama. Teamwork yang solid akan 
membuat karyawan dapat memperlihatkan kerjasama dan rasa tanggung jawab pada pekerjaannya, membuat perputaran dan kemangkiran yang lebih rendah, dan terlebih penting akan membuat karyawan memiliki semangat kerja yang lebih baik.

Selain teamwork, penghargaan merupakan alat pengendali penting yang digunakan perusahaan untuk meningkatkan semangat kerja karyawannya. Penghargaan dapat didefinisikan sebagai segala sesuatu yang diterima karyawan atas balas jasa kerjanya. Kinerja dipengaruhi oleh bagaimana puasnya karyawan pada penghargaan yang diterimanya, karena itu sistem penghargaan harus juga mendorong kepuasan karyawan, ketidakpuasan akan muncul dalam kinerja yang rendah yang akan menyebabkan lebih banyak pemogokan dan keluhan, ketidakhadiran, perputaran karyawan yang tinggi, dan lain-lain. Pada saat dikelola secara baik, penghargaan akan membantu organisasi mencapai tujuannya, dan memperoleh, memelihara dan mempertahankan semangat kerja karyawannya.

Kinerja dipengaruhi oleh faktor yang berasal dari dalam diri pribadi mental psikologis karyawan yang bersangkutan dan juga faktor yang berasal dari luar antara lain pemberian fasilitas, gaji, penghargaan, dan lainlain. Kinerja yang baik ditandai dengan adanya kesenangan, gairah kerja karyawan yang tinggi dalam melaksanakan pekerjaan, serta adanya kemauan bekerjasama dengan karyawan lain (teamwork) untuk mencapai tujuan bersama.

Tujuan dari penelitian ini adalah sebagai berikut: (1) Untuk mengetahui dan menganilisis pengaruh teamwork pada kinerja karyawan hotel bintang tiga di Surabaya. (2) Untuk mengetahui dan menganalisis pengaruh penghargaan pada kinerja karyawan hotel bintang tiga di Surabaya. (3) Untuk mengetahui dan menganalisis variabel yang dominan berpengaruh pada kinerja karyawan hotel bintang tiga di Surabaya.

\section{Kajian Teoritis dan Hipotesis}

Teamwork

Teamwork merupakan salah satu unsur fundamental dalam manajemen sumberdaya manusia. Teamwork merupakan sekelompok orang yang memiliki tujuan bersama akan tetapi tidak semua kumpulan orang dapat dikatakan Teamwork. Menurut Johnson (dalam Arizona, 2017). Untuk dapat dianggap sebagai tim, sekelompok orang tersebut harus memiliki karakteristik, sebagai berikut: Ada kesepakatan terhadap misi tim, semua anggota mentaati peraturan tim yang berlaku, ada pembagian tanggung jawab dan wewenang yang ada, ada orang yang mau beradaptasi terhadap perubahan. Bell, (2007) mengatakan bahwa dengan berbagai sumberdaya yang tersedia dan tugas yang relevan serta seberapa baik anggota tim berkomunikasi dan bekerjasama dengan satu sama lain, komposisi tim diyakini memiliki dampak yang kuat pada kinerja tim. Kearney, Gebert, dan Voelpel (2009) berpendapat bahwa "Both the elaboration of task-relevant information and collective team identification mediated a moderating effect of need for cognition on the relationship between both types of diversity and team performance."

Jika karyawan bertindak sebagai kelompok dari individu-individu yang memperhatikan tujuan-tujuan individual akan memboroskan waktu, tenaga, usaha dan sumberdaya, sering kehilangan tujuan kelompok atau bahkan membuat tujuan itu tidak mungkin dicapai. Bila karyawan bertindak sebagai tim, maka pekerjaan akan berhasil (Goetsch \& Davis, 2002; Arizona, 2017).

Anggota-anggota tim yang dilibatkan harus dibuat agar memiliki perasaan identik yang kuat dalam kelompok agar bisa menjadi sebuah teamwork yang solid (Allen \& Hecht, 2004). Ada beberapa manfaat bekerja sebagai tim yaitu: memperbaiki semangat kerja dan motivasi, mengurangi pergantian staf, meningkatkan produktivitas, meningkatkan kepuasan kerja, jauh lebih mudah untuk mengatasi masalah ketika setiap orang bekerjasama.

Yunizel (1997) mengatakan bahwa: Pentingnya kerjasama tim menjadi sebuah teamwork yang solid untuk meningkatkan manajemen sumberdaya manusia. Kerjasama tim yang memengaruhi manajemen sumberdaya manusia yaitu: (1) kesamaan visi; (2) memiliki rasa kebersamaan; (3) pemberdayaan; (4) penyelesaian masalah dengan bekerjasama dalam perbedaan; (5) refleksi pengalaman untuk pengembangan".

Menurut Pokras (2004), anggota tim perlu: (1) berbagi pekerjaan tim, berkontribusi pada piagam dan rencana tim, berbagai tanggung jawab, (2) melaksanakan peran, taat pada rencana dan membantu menyelesaikan masalah, (3) mewakili tim dan memberi penjelasan kepada orang luar, sering menghubungi pelanggan, mengumpulkan masukan dari pelanggan, (4) bersedia berkontribusi, berlatih, membaca catatan, menyelesaikan tindakan, mengumpulkan informasi, bertemu dengan pemimpin tim dan siap mengikuti rapat, (5) berpartisipasi dalam rapat, hadir tepat waktu di semua rapat tim berpartisipasi dengan penuh, memberikan saran keahlian, mendengarkan, berkomunikasi secara terbuka, taat pada peraturan dasar dan bekerja untuk mencapai tujuan. 
Salah satu pendekatan komunikasi yang paling berhasil dalam organisasi adalah pengarahan tim. Sebuah sistem yang dipelopori oleh masyarakat industri. Pendekatan yang menyeluruh ini melibatkan keseluruhan perusahaan dari atas sampai bawah. Semua pemimpin tim diberikan pengarahan. Selanjutnya pemimpin tim akan memberikan pengarahan pada timnya masing-masing.

Pelatihan tim, tidak hanya sekedar cara untuk mengajarkan keahlian praktis yang harus kepada anggota tim. Menurut Allen dan Hecht (2004), pelatihan juga mempunyai beberapa manfaat lain sebagai berikut: (1) Pelatihan adalah cara yang sangat baik untuk mengajarkan keahlian umum seperti, mendengar dan bekerjasama dalam teamwork. (2) Pelatihan membuat orang yang dilatih merasa dibutuhkan dan berharga. (3) Pelatihan akan memotivasi anggota-anggota tim karena untuk memudahkan menjalankan keahlian baru sehingga dapat menjalankan tugas, tanggung jawab dan tantangan baru. (4) Jika tim dilatih secara kolektif, maka hal itu akan semakin mendekatkan sebagai sebuah teamwork. Ketika anggota tim saling menunjukkan kelemahan masingmasing dan mengidentifikasi potensi masing-masing yang sebelumnya tidak pernah diketahui. (5) Pelatihan anggota-anggota tim sebagai satu teamwork juga mendorong menerapkan pelajaran yang didapatkan ketika kembali bekerja. Anggota tim mengetahui apa yang dipelajari masing-masing, sehingga akan saling mendukung dan membantu, serta saling mengingatkan ketika lupa pelajaran tersebut.

Membangun semangat tim merupakan fungsi manajerial yang paling vital. Sulit untuk mempertahankan semangat teamwork. Menurut Allen dan Hecht (2004), beberapa teknik dan pendekatan untuk membangun semangat kerja tim adalah:

1. Mendorong anggota tim untuk saling mendukung satu dengan lainnya. Jika seorang anggota tim membutuhkan saran atau bantuan, maka anggota tim yang lainnya wajib membantu, agar tercipta rasa kebersamaan.

2. Melatih tim secara bersama-sama. Pelatihan kelompok dapat mengumpulkan anggota-anggota tim secara bersama-sama. Bentuk pelatihan apapun tentang organisasi sebagai satu kesatuan dan peran tim dalam organisasi sangat berguna dan harus dilakukan sebagai sebuah kelompok.

3. Menempatkan anggota-anggota tim yang berbeda pada proyek yang berbeda. Hal ini untuk menjaga tim betapa dinamis dan mendorong adanya rasa saling menghormati, dan untuk membantu anggota tim untuk mengenal anggota-anggota tim yang bertanggungjawab atas tugas tertentu, sehingga tidak terjadi saling melempar tugas dan tanggung jawab.

4. Memberikan informasi rahasia kepada tim. Hal ini akan membuat anggota-anggota tim merasa dipercaya.

5. Memperlakukan setiap orang sebagai bagian dari tim. Perasaan kebersamaan tidak akan bisa tercipta jika anggota-anggota tim tidak diberi perlakuan yang sama. Setiap anggota tim harus selalu diperlakukan dengan rasa hormat yang sama, tanpa membeda-bedakan satu sama lainnya memecahkan masalah, menggunakan proses pengendalian statistik. Membaca bagan, merancang kerangka acuan kerja dan tidak hentinya mengadakan perbaikan.

6. Manajemen pekerjaan dan proyek. Bagaimana mengkoordinasikan usaha, mengukur mutu, memantau kemajuan, berinteraksi dengan penanggung risiko, mengelola keuangan, mengendalikan biaya, dan mendokumentasikan tindakan.

7. Keterampilan teknis. Bagaimana memahami sistem, melaksanakan fungsi, mengoperasikan peralatan, dan memperbaiki proses yang menjadi tanggung jawab tim.

\section{Penghargaan}

Menurut Mulyadi dan Setyawan (1999): "Penghargaan merupakan salah satu alat pengendalian penting yang digunakan oleh perusahaan untuk memotivasi personel agar mencapai tujuan (bukan tujuan personel secara individual) dengan perilaku sesuai dengan yang diharapkan oleh perusahaan (bukan perilaku yang disukai oleh personel secara pribadi”.

Pengertian penghargaan menurut Handoko (2000) adalah "segala sesuatu yang diterima para karyawan sebagai balas jasa." Dengan demikian salah satu fungsi tradisional manajemen sumberdaya manusia adalah penentuan penghargaan para karyawannya. Menurut Ichiowski seperti yang dikutip oleh Kurnianingsih dan Indriantoro (2001), "Kinerja yang tinggi pada dasarnya tergantung pada program pemberian insentif jika dihubungkan dengan pekerjaan yang mendukung, meliputi penilaian kerja, informasi yang merata dan keamanan kerja."

Menurut Dessler (1997), "Penghargaan merupakan setiap bentuk pembayaran atau imbalan yang diberikan kepada karyawan dan timbul dari kebijakannya karyawan itu atau dalam kata lain penghargaan merupakan ganti kontribusi karyawan kepada organisasi." 


\section{Karakteristik Penghargaan}

Menurut Mulyadi dan Setyawan (1999), kriteria penghargaan adalah:

a. Penghargaan harus dihargai oleh penerima. Penghargaan yang tidak bernilai diminta menerima tidak akan memotivasi penerima untuk berprestasi.

b. Penghargaan harus cukup besar untuk dapat memiliki dampak. Jika penghargaan yang disediakan jumlahnya tidak signifikan, dampaknya dapat berlawanan dengan usaha untuk meningkatkan produktivitas.

c. Penghargaan harus dapat dimengerti oleh penerima. Karyawan harus memahami dengan baik mengenai alasan pemberian penghargaan maupun nilai penghargaan yang diterima.

d. Penghargaan harus diberikan pada waktu yang tepat. Penghargaan harus diberikan segera setelah karyawan menghasilkan kinerja yang seharusnya mendapatkan penghargaan.

e. Dampak penghargaan harus dirasakan dalam jangka panjang. Penghargaan dapat menghasilkan nilai yang lebih tinggi jika perasaan bahagia yang dihasilkan oleh penghargaan tersebut bertahan lama dalam ingatan penerima.

f. Penghargaan harus dapat diubah. Pemberian penghargaan seringkali berbuat salah dalam menetapkan penghargaan, dan beberapa keputusan pemberian penghargaan lebih sulit untuk diubah dibandingkan dengan yang lain.

g. Penghargaan harus memerlukan biaya yang efisien. Penghargaan yang terbaik adalah penghargaan yang mampu memotivasi personel sesuai dengan yang diharapkan oleh perusahaan dengan biaya yang minimum.

\section{Tujuan Pemberian Penghargaan}

Menurut Sedarmayanti (2001), tujuan sistem penghargaan yang baik antara lain sebagai berikut:

a. Menghargai prestasi kerja. Pemberian penghargaan yang baik oleh suatu organisasi pada prestasi kerja para pegawainya, akan mendorong kinerja pegawai.

b. Menjamin keadilan. Adanya sistem penghargaan yang baik, akan menjamin adanya keadilan di antara pegawai dalam organisasi.

c. Mempertahankan pegawai. Sistem penghargaan yang baik, pegawai akan lebih bertahan bekerja pada organisasi.

d. Memperoleh pegawai yang bermutu. Sistem penghargaan yang baik akan menarik lebih banyak calon pegawai, dengan banyaknya pelamar maka peluang untuk memilih pegawai yang bermutu lebih besar.

e. Pengendalian biaya. Sistem penghargaan yang baik, akan mengurangi seringnya rekruitmen sebagai akibat dari seringnya pegawai yang keluar.

f. Memenuhi peraturan. Suatu organisasi yang baik dituntut untuk memiliki sistem administrasi penghargaan yang baik.

Menurut Mulyadi dan Setyawan (1999), penghargaan dapat digolongkan ke dalam dua kelompok, yaitu:

a. Penghargaan intrinsik, berupa rasa puas dari yang diperoleh seseorang yang telah berhasil menyelesaikan pekerjaannya dengan baik dan telah mencapai sasaran tertentu.

b. Penghargaan ekstrinsik, terdiri dari kompensasi yang diberikan kepada personel, baik yang berupa kompensasi langsung, tidak langsung maupun yang berupa kompensasi non moneter.

Menurut jenis-jenis penghargaan menurut Mathis dan Jackson (2006) dibedakan kedalam dua kategori, yaitu penghargaan instrinsik dan penghargaan ekstrinsik.

a. Penghargaan intrinsik. Penghargaan intrinsik sering meliputi pujian atas penyelesaian sebuah proyek atau pemenuhan tujuan kinerja. Mathis dan Jackson (2006), bahwa penghargaan intrinsik meliputi efek psikologis dan sosial.

b. Penghargaan ekstrinsik. Penghargaan ekstrinsik adalah penghargaan yang nyata berupa penghargaan moneter dan non moneter.

Untuk merancang sistem penghargaan finansial khususnya gaji, dan upah, menurut Simamora, (2002) dapat mempertimbangkan faktor-faktor, seperti berikut: keadilan, kemampuan organisasi, mengaitkan dengan prestasi, harus memperhatikan peraturan pemerintah, kompetitif. Menurut Mulyadi dan Setyawan (1999), penghargaan menghasilkan dua macam manfaat, antara lain:

a. Memberi informasi. Penghargaan dapat menarik perhatian dan memberi informasi atau mengingatkan tentang pentingnya sesuatu yang diberi penghargaan dibandingkan dengan yang lain.

b. Memberi motivasi. Penghargaan akan meningkatkan motivasi pada ukuran kinerja, sehingga membantu dalam memutuskan bagaimana mengalokasikan waktu dan usaha. 


\section{Kinerja}

Menurut Nawawi (2003), mengatakan bahwa kinerja diartikan sebagai tingkat efektivitas dan efisiensi pelaksanaan pekerjaan (performance) yang menghasilkan prestasi kerja, yang dikategorikan produktif dari segi jumlah (kuantitas), nilai internal berupa kualitas proses dalam menghasilkan sesuatu dan nilai eksternal berupa kualitas hasilnya. Menurut Mangkunegara (2005a) faktor-faktor yang memengaruhi kinerja, yaitu:

1. Faktor kemampuan. Secara psikologis, kemampuan (ability) pegawai terdiri dari kemampuan potensi (IQ) dan kemampuan realitas (knowledge and skills).

2. Faktor Motivasi. Motivasi terbentuk dari sikap (attitude) seorang pegawai dalam menghadapi situasi kerja. Motivasi merupakan kondisi yang menggerakkan diri pegawai yang terarah untuk mencapai tujuan organisasi (tujuan kerja).

Hellriegel, Slocum, dan Woodman (1998) menyatakan kinerja individu sebagai hasil perkalian atau fungsi dari motivasi dan kemampuan. Formula kinerja adalah sebagai berikut Kinerja $(\mathrm{P})=$ fungsi $($ Kemampuan dan Motivasi); atau performance $=f$ (ability $x$ motivation). Gibson, Ivancevich, dan Donnelly (1996) menyatakan bahwa tingkat kinerja karyawan merupakan suatu ukuran yang dapat digunakan untuk menetapkan perbandingan hasil pelaksanaan tugas, tanggung jawab yang diberikan oleh organisasi pada periode tertentu dan relatif dapat digunakan untuk mengukur prestasi kerja atau kinerja organisasi. Penilaian kinerja adalah proses penilaian dari ciri-ciri kepribadian, perilaku kerja, dan hasil kerja seorang tenaga kerja/karyawan (perkerja dan manajer), yang dianggap menunjang prestasi kerjanya, yang digunakan sebagai bahan pertimbangan untuk pengambilan keputusan tentang tindakan-tindakan terhadapnya di bidang ketenagakerjaan (Munandar, 2001).

\section{Kerangka Pemikiran}

Menurut Sugiyono (2017) mengemukakan bahwa, kerangka berpikir merupakan model konseptual tentang bagaimana teori berhubungan dengan berbagai faktor yang telah diidentifikasi sebagaimasalah yang penting. Kerangka pemikiran dalam penelitian ini adalah Teamwork $\left(X_{I}\right)$ dan Penghargaan $\left(X_{2}\right)$ sebagai variabel bebas dan Kinerja Karyawan $(Y)$ sebagai variabel terikat. Gambar 1 adalah gambaran kerangka berpikir dalam penelitian ini.

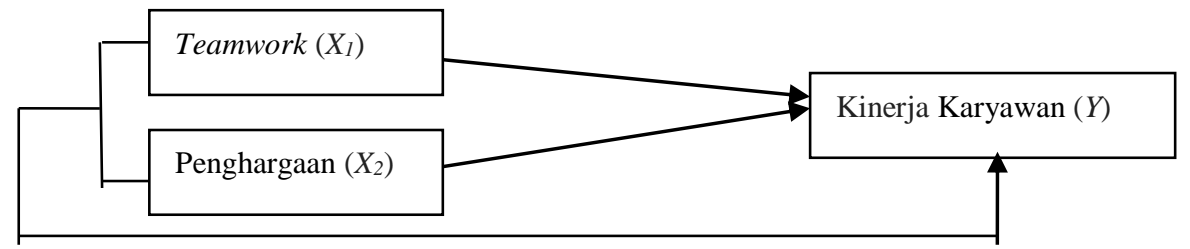

Gambar 1. Kerangka pemikiran

\section{Hipotesis Penelitian}

Berdasarkan rumusan masalah yang mengacu pada kajian teori yang telah dikemukakan sebelumnya, maka dapat dirumuskan hipotesis penelitian, sebagai berikut:

1. $H_{H}$ : Terdapat pengaruh teamwork pada kinerja karyawan hotel bintang tiga di Surabaya.

2. $H_{2}$ : Terdapat pengaruh penghargaan pada kinerja karyawan hotel bintang tiga di Surabaya.

3. $H_{3}$ : Penghargaan berpengaruh dominan pada kinerja karyawan hotel bintang tiga di Surabaya.

\section{Metode Penelitian}

Dalam penelitian ini menggunakan model penelitian kuantitatif dengan menggunakan pendekatan deskriptif. Dalam penelitian ini variabel-variabel yang diteliti, sebagai berikut: Variabel bebas ialah Teamwork $\left(X_{I}\right)$, Penghargaan $\left(X_{2}\right)$ dan variabel tergantung ialah kinerja $(Y)$.

\section{Definisi Operasional}

Teamwork merupakan salah satu unsur Fundamental dalam manajemen sumberdaya manusia. Teamwork merupakan sekelompok orang yang memiliki tujuan bersama. West (dalam Hatta, Musnadi, \& Mahdani, 2017) menetapkan indikator-indikator kerjasama tim (teamwork) sebagai alat ukurnya, sebagai berikut:

a. Tanggung jawab, yaitu secara bersama-sama menyelesaikan pekerjaan, yaitu dengan pemberian tanggung jawab dapat tercipta kerjasama yang baik.

b. Saling berkontribusi, yaitu dengan saling berkontribusi baik tenaga maupun pikiran akan terciptanya kerjasama.

c. Pengerahan kemampuan secara maksimal, yaitu dengan mengerahkan kemampuan masing-masing anggota tim secara maksimal, kerjasama akan lebih kuat dan berkualitas. 
Penghargaan dapat didefinisikan sebagai segala sesuatu yang diterima karyawan atas balas jasa kerja. Menurut Kadarisman (2012), indikator penghargaan, sebagai berikut: 1) Upah; 2). Gaji; 3). Insentif; 4) Tunjangan; 5) Penghargaan Interpersonal; 6) Promosi.

Kinerja Karyawan dipengaruhi oleh bagaimana puasnya karyawan pada penghargaan yang diterimanya, karena itu sistem penghargaan harus juga mendorong kepuasan karyawan, ketidakpuasan akan muncul dalam kinerja yang rendah yang akan menyebabkan lebih banyak pemogokan dan keluhan, ketidakhadiran, perputaran karyawan yang tinggi, dan lain-lain. Menurut Robbins (dalam Bintoro \& Daryanto 2017) kinerja karyawan memiliki enam indikator, yaitu:

a. Kualitas. Kualitas kerja diukur dari persepsi karyawa pada kualitas pekerjaan yang dihasilkan serta kesempurnaan tugas pada keterampilan dan kemampuan karyawan.

b. Kuantitas. Merupakan jumlah yang dihasilkan dinyatakan dalam istilah seperti jumlah unit, jumlah siklus aktivitas yang diselesaikan.

c. Ketepatan Waktu. Merupakan tingkat aktivitas diselesaikan pada awal waktu yang dinyatakan, dilihat dari sudut koordinasi dengan hasil output serta memaksimalkan waktu yang tersedia untuk aktivitas lain.

d. Efektivitas. Merupakan tingkat penggunaan sumberdaya organisasi (tenaga, uang, teknologi, bahan baku) dimaksimalkan dengan maksud menaikkan hasil dari setiap unit dalam penggunaan sumberdaya.

e. Kemandirian. Merupakan tingkat seseorang karyawan yang nantinya akan dapat menjalankan tugas kerjanya.

f. Komitmen kerja. Merupakan suatu tingkat komitmen kerja karyawan dengan instansi dan tanggung jawab karyawan pada kantor.

\section{Teknik Penentuan Sampel}

Populasi yang digunakan dalam penelitian ini adalah karyawan hotel bintang tiga Surabaya sebanyak 134 orang. Sampel adalah bagian dari sebuah populasi, yang mempunyai ciri dan karakteristik yang sama dengan populasi tersebut, karena itu jumlah sampel harus merupakan representatif dari sebuah populasi (Sumarsono, 2002). Teknik pengambilan sampel menggunakan teknik probability sampling karena populasi memiliki peluang yang besarnya sudah diketahui untuk terpilih sebagai sampel dan peneliti bisa memperkirakan besarnya kesalahan dalam penarikan sampel. Untuk menentukan ukuran sampel dari suatu populasi digunakan rumus Slovin (Umar, 2002).

$$
\begin{aligned}
& n=\frac{N}{1+N e^{2}} \\
& n=\frac{134}{1+134(0,05)^{2}} \\
& n=\frac{134}{1,335} \\
& n=100.37 \\
& n=100
\end{aligned}
$$

Jadi sampel penelitian adalah 100 responden dari populasi sebanyak 134 karyawan hotel bintang tiga Surabaya.

\section{Analisis Data dan Pembahasan \\ Analisis Regresi Berganda}

Ada tidaknya pengaruh teamwork dan penghargaan pada semangat kerja digunakan model Regresi Linier Berganda. Hasil perhitungan dengan bantuan program komputer SPSS 11.5 (Statistical Program for Social Sience) didapat nilai koefisien regresi, sebagai berikut (Tabel 3):

Tabel 3

Ringkasan Hasil Analisis Pengaruh Teamwork dan Penghargaan pada Kinerja Karyawan

\begin{tabular}{lcccc}
\hline \multicolumn{1}{c}{ Variabel } & Koefisien Regresi & Galat Baku & Nilai $\boldsymbol{t}$ & Korelasi Parsial \\
\hline Teamwork $\left(X_{1}\right)$ & 0,447 & 0,051 & 8,759 & 0,665 \\
Penghargaan $\left(X_{2}\right)$ & 0,534 & 0,051 & 10,563 & 0,731 \\
Konstanta $=0,122$ & & $F(0,05: 2: 97)$ & $=3,09$ & \\
$F \quad=17,407$ & & $R^{2}$ & $=0,779$ & \\
& & Multiple $R$ & $=0,883$ & \\
\hline
\end{tabular}


Dari nilai standar koefisien regresi ditetapkan persamaan, sebagai berikut:

$Y=b_{o}+b_{1} X_{1}+b_{2} X_{2}+e$

$Y=0,122+0,447 X_{1}+0,534 X_{2}+0,206$

Koefisien regresi untuk teamwork $\left(X_{I}\right)$ adalah sebesar 0,447 bernilai positif, yang artinya apabila teamwork $\left(X_{I}\right)$ naik sebesar satu satuan dapat menyebabkan kenaikan kinerja karyawan $(Y)$ sebesar 0,447 satuan. Koefisien regresi untuk penghargaan $\left(X_{2}\right)$ adalah sebesar 0,534 bernilai positif, yang artinya apabila penghargaan $\left(X_{2}\right)$ naik sebesar 1 satuan dapat menyebabkan kenaikan kinerja karyawan $(Y)$ sebesar 0,534 satuan.

Dari hasil pengolahan menunjukkan bahwa pengaruh yang paling dominan dilihat dari koefisien regresi adalah variabel penghargaan hal itu ditunjukkan dengan nilai koefisien regresi sebesar 0,534.

Untuk mengetahui pengaruh hubungan atau kontribusi yang diberikan variabel bebas kepada variabel terikatnya dapat dilihat dari nilai $R^{2}$ (koefisien determinasi). Dari hasil pengolahan data didapatkan nilai $R^{2}$ (koefisien determinasi) sebesar 0,779 (Tabel 3), yang menunjukkan bahwa teamwork dan penghargaan secara bersama-sama memberikan kontribusi pada kinerja sebesar $77,9 \%$. Sisanya sebesar $22,1 \%$ dipengaruhi oleh variabel lain di luar model ini.

\section{Uji Kelayakan Model Menggunakan Uji F}

Dari hasil pengolahan data didapatkan nilai $F$-hitung sebesar 17,407 (Tabel 4), untuk melihat F-tabel digunakan $d f(n-k-1)$ sebesar 97 (100-2-1) didapatkan nilai $F$-tabel 3,09 (Tabel 3) dan nilai signifikansi sebesar 0,000. Hasil F-hitung > F-tabel $(17,407>3,09)$ dan nilai Sig. $<0,05(0,00<0,05)$, maka dapat disimpulkan bahwa model regresi layak menjelaskan pengaruh variabel teamwork dan penghargaan pada kinerja karyawan.

Tabel 4

Uji $F\left(\right.$ ANOVA $\left.^{\text {b }}\right)$

\begin{tabular}{clcccc}
\hline Model & Sum of Squares & $\boldsymbol{d f}$ & Mean Square & $\boldsymbol{F}$ & Sig. \\
\hline \multirow{2}{*}{1} & Regression & 34,814 & 2 & 17,407 & $000^{\mathrm{a}}$ \\
& Residual & 9,852 & 97 & 102 & \\
& Total & 44,666 & 99 & & \\
\hline
\end{tabular}

a. Predictors: (Constant), Penghargaan, Teamwork

b. Dependent Variable: Kinerja Karyawan

\section{Pengujian Hipotesis Menggunakan Uji t}

Untuk mengetahui pengaruh secara parsial dari masing-masing variabel, teamwork $\left(X_{I}\right)$ dan penghargaan $\left(X_{2}\right)$ pada kinerja $(Y)$ digunakan uji $t$ dengan $d f$ sebesar $97(n-k-1)$ untuk melihat $t$-tabel didapatkan nilat $t$-tabel 1,9847 .

\section{a) Teamwork $\left(X_{I}\right)$}

Dari hasil pengolahan data, diperoleh nilai thitung sebesar 8,759 (Tabel 3), sedangkan nilai t-tabel dengan $d f$ sebesar 97 (n-k-1) adalah sebesar 1,9847. Karena t-hitung sebesar 8,759 lebih besar dari t-tabel sebesar 1,9847, maka $\mathrm{Ho}$ ditolak dan $\mathrm{Hi}$ diterima, artinya teamwork memengaruhi kinerja karyawan, untuk lebih jelasnya dapat dilihat pada Tabel 5 .

b) Penghargaan $\left(X_{2}\right)$

Dari hasil pengolahan data, diperoleh nilai t-hitung sebesar 10,563 (Tabel 3), sedangkan nilai $t$-tabel dengan $d f$ sebesar $97(n-k-1)$ adalah sebesar 1,9847. Karena t-hitung sebesar 10,563 lebih besar dari t-tabel sebesar 1,9847, maka $\mathrm{Ho}$ ditolak dan $\mathrm{Hi}$ diterima, artinya penghargaan memengaruhi kinerja karyawan, untuk lebih jelasnya dapat dilihat pada Tabel 5 .

Dari hasil analisis yang telah dilakukan, maka hipotesis penelitian yang menyatakan bahwa teamwork dan penghargaan berpengaruh pada kinerja adalah terbukti. Hipotesis yang menyatakan bahwa penghargaan berpengaruh dominan pada kinerja karyawan juga terbukti sebagaimana terlihat dari nilai koefisien regresi variabel penghargaan sebesar 0,534 atau $53,4 \%$ dan dari uji $t$ nilai parsial variabel penghargaan sebesar 0,731 atau $73,1 \%$.

Berdasarkan hasil pengujian hipotesis penelitian didapatkan bahwa teamwork dengan nilai $t$-hitung 8,759 lebih besar dari t-tabel 1,9847 berpengaruh pada kinerja pada hotel bintang tiga di Surabaya. Hal ini menunjukkan bahwa menejemen hotel sudah mengusahakan teamwork yang baik dan agar dapat dipertimbangkan bagi karyawan untuk meningkatkan kinerja karyawan. Saat ini hotel bintang tiga di Surabaya sudah dapat menempatkan teamwork sesuai dengan keinginan karyawannya. 
Penghargaan berpengaruh dominan. Hal ini menunjukkan bahwa dengan penghargaan yang diinginkan oleh karyawan pada hotel bintang tiga di Surabaya merupakan alat terpenting yang dapat digunakan untuk membangkitkan kinerja karyawan demi mencapai tujuan dan sasaran yang sudah ditetapkan.

\section{Tabel 5}

Hasil Perhitungan dengan Uji $t$

\begin{tabular}{ccccc}
\hline & t-tabel & t-hitung & Hasil Pengujian & Pengaruh \\
\hline Teamwork & $\pm 1,9847$ & 8,759 & Ho ditolak & Signifikan \\
Penghargaan & $\pm 1,9847$ & 10,563 & Ho ditolak & Signifikan \\
\hline
\end{tabular}

\section{Simpulan, Keterbatasan, dan Saran}

Berdasarkan analisis penelitian, maka dapat diambil suatu kesimpulan yang sesuai dengan rumusan masalah dan tujuan yang telah ditetapkan, sebagai berikut: teamwork berpengaruh pada kinerja karyawan, penghargaan berpengaruh pada kinerja karyawan, dan variabel penghargaan merupakan variabel dominan yang memengaruhi kinerja karyawan hotel bintang tiga di Surabaya.

Keterbatasan dalam penelitian ini ialah tidak adanya informasi akurat jumlah karyawan hotel bintang tiga di Surabaya, tidak dilakukan pembahasan yang mempertimbangkan data jenis-jenis penghargaaan yang telah diberikan oleh masing-masing hotel.

Dengan memperhatikan kesimpulan tersebut, maka dapat dikemukakan saran-saran yang diharapkan mempunyai manfaat dan dapat digunakan sebagai bahan pertimbangan pada hotel bintang tiga di Surabaya di masa yang akan datang, sebagai berikut: Dalam penelitian yang telah dilakukan terbukti bahwa teamwork dan penghargaan mempunyai pengaruh pada kinerja karyawan pada hotel bintang tiga di Surabaya. Oleh sebab itu sebaiknya setiap karyawan di masing-masing departemen/ bagian bersedia memperbaiki perilakunya dalam membina hubungan kerja dengan karyawan dalam satu departemen dan departemen lainnya, supaya tercipta teamwork yang solid. Perusahaan juga harus merancang penghargaan yang sesuai dengan kinerja karyawan untuk memacu kinerjanya. Perusahaan hendaknya memperhatikan penghargaan yang telah diberikan kepada karyawannya, didasarkan pada pencapaian sasaran teamwork yang ada pada hotel bintang tiga di Surabaya. Perusahaan dapat mencegah labour turnover (tingkat perpindahan karyawan) dengan memberikan penghargaan kepada karyawan sebagai upaya untuk mempertahankan karyawan yang berkualitas, sehingga tujuan perusahaan tercapai.

\section{Referensi}

Allen, N. J., \& Hecht, T. D. (2004). The 'romance of teams': Toward an understanding of its psychological underpinnings and implications. Journal of Occupational and Organizational Psychology, 77(4), 439-461. https://doi.org/10.1348/0963179042596469

Arizona, R. (2017). Peran teamwork dalam upaya meningkatkan kinerja karyawan pada PT. Asuransi Sinarmas Cabang Malang, Jurnal Aplikasi Administrasi, 20(1), 52-60.

Bell, S. T. (2007). Deep-level composition variable as predictors of team performance: Meta- analysis. Journal of Applied Psychology, 92, 595-615.

Bintoro \& Daryanto (2017). Manajemen penilaian kinerja karyawan. Yogyakarta: Penerbit Gava Media.

Dessler, G. (1997). Manajemen sumber daya manusia. Jakarta: PT Gramedia Pustaka Utama.

Gibson, J. L., Ivancevich, J. M., \& Donnelly, J. H. Jr. (1996). Organisasi, perilaku, struktur, proses, (Alih Bahasa Nunuk Adiarni). Jakarta: Penerbit Binarupa Aksara.

Goetsch, D. L., \& Davis, S. (2002). Introduction to total quality: Quality, productivity, competitiveness. Englewood Cliffs, NJ: Pretince-Hall International Inc.

Handoko, H. (2000). Manajemen personalia dan sumberdaya manusia. Yogyakarta: Liberty.

Hatta, M., Musnadi, S., \& Mahdani. (2017). Pengaruh gaya kepemimpinan, kerjasama tim dan kompensaasi terhadap kepuasan kerja serta dampaknya pada kinerja karyawan PT PLN (Persero) wilayah Aceh. Jurnal Magister Manajemen Fakultas Ekonomi dan Bisnis Unsyiah, 1(1), 70-80.

Hellriegel, D., Slocum, J. W., \& Woodman, R. W. (1998). Organizational Behavior, 8th ed. Cincinnati, OH: South-Western College.

Indah, P. P. A. P., Rahmawati, P. I., \& Andiani, N. D. (2019). Pengaruh sistem penghargaan (reward) terhadap kinerja trainee di Hotel Holiday Inn Resort Baruna Bali. Jurnal Manajemen Perhotelan dan Pariwisata, $2(1), 41-54$. 
Kadarisman, M. (2012). Manajemen kompensasi. Depok: Raja Grafindo Persada.

Kearney, E., Gebert, D., \& Voelpel, S. C. (2009). When and how diversity benefits teams: The importance of team members' need for cognition. Academy of Management Journal, 52(3), 581-598.

Kurnianingsih, R., \& Indriantoro, N. (2001). Pengaruh sistem pengukuran kinerja dan sistem penghargaan terhadap keefektifan penerangan teknik total quality management (Studi empiris pada perusahaan manufaktur di Indonesia). The Indonesian Journal of Accounting Research (IJAR), 4(1). http://doi.org/10.33312/ijar.49

Mangkunegara, A. P. (2005a). Evaluasi kinerja SDM. Bandung: Refika Aditama.

Mangkunegara, A. P. (2005b). Manajemen sumberdaya manusia perusahaan. Bandung: Remaja Rosdakarya.

Mathis, R. L., \& Jackson, J. H. (2006). Manajemen sumberdaya manusia, Edisi Kesepuluh. Jakarta: Salemba Empat.

Moekijat. (2002) Dasar-dasar motivasi. Jakarta: CV. Pionir Jaya.

Mulyadi \& Setyawan. J. (1999). Sistem perencanaan dan pengendalian manajemen: Sistem pelipat ganda kinerja perusahaan. Edisi 1, Cetakan Kesatu. Yogyakarta: Penerbit Aditya Media.

Munandar, A. S. (2001). Psikologi industri dan organisasi. Jakarta: UI.

Nawawi, H. (2003). Kepemimpinan mengefektifkan organisasi. Yogyakarta: Gadjah Mada University Press.

Pokras, S. (2004). Building high performance team: Membangun tim berkinerja tinggi. Jakarta: PT. Elexmedia Komputindo.

Sedarmayanti. (2001). Sumber daya manusia dan produktivitas kerja. Bandung: Mandar Maju.

Sugiyono (2017). Metode penelitian kuantitatif, kualitatif, dan R\&D. Bandung: CV Alfabeta.

Sumarsono. (2002). Sosiolinguistik. Yogyakarta: Pustaka Pelajar.

Umar, H. (2002). Metode penelitian untuk skripsi dan tesis bisnis. Jakarta: Raja Grafindo Persada.

Yunizel. (1997). Optimasi peran teamwork sebagai basis persaingan. Usahawan No. 05 Th. IXX Desember 1997, Lembaga Manajemen Fakultas Ekonomi. Universitas Indonesia. 